\title{
Postconditioning ameliorates lipid peroxidation in liver ischemia-reperfusion injury in rats $^{1}$
}

\author{
Pós-condicionamento melhora a peroxidação lipídica na lesão de isquemia-reperfusão hepática \\ em ratos
}

\begin{abstract}
Antonio Roberto Franchi Teixeira', Nilza T. Molan" ${ }^{\mathrm{II}}$, Márcia Saldanha Kubrusly ${ }^{\mathrm{II}}$, Marta Bellodi-Privato ${ }^{\mathrm{II}}$, Ana Maria Coelho" Kátia R. Leite ${ }^{\mathrm{IV}}$, Marcel Autran Cesar Machadov , Telésforo Bacchella ${ }^{\mathrm{VI}}$, Marcel Cerqueira César Machado ${ }^{\mathrm{VII}}$

${ }^{I}$ Ph.D., Assistant Surgeon, Liver Transplantation and Surgery Unit, Department of Gastroenterology, Faculty of Medicine, University of Sao Paulo, Brazil.

II Pharmacist, Liver Transplantation and Surgery Unit, Department of Gastroenterology, Faculty of Medicine, University of Sao Paulo, Brazil.

III Pharmacist, Post-Doctorate, Liver Transplantation and Surgery Unit, Department of Gastroenterology, Faculty of Medicine, University of Sao Paulo, Brazil.

Iv Ph.D., Pathologist, Department of Urology, Faculty of Medicine, University of Sao Paulo, Brazil.

v Professor, Liver Transplantation and Surgery Unit, Department of Gastroenterology, Faculty of Medicine, University of Sao Paulo, Brazil

${ }^{V I}$ Full Professor and Surgeon-in Chief, Liver Transplantation and Surgery Unit, Department of Gastroenterology, Faculty of Medicine, University of Sao Paulo, Brazil.

${ }^{\mathrm{VII}}$ Former Chairman, Liver Transplantation and Surgery Unit, Department of Gastroenterology, Faculty of Medicine, University of Sao Paulo, Brazil.
\end{abstract}

\begin{abstract}
Purpose: Liver ischemia-reperfusion injury is a phenomenon presents in events like liver resections and transplantation. The restoration of blood flow may leads to local and systemic injury. Several techniques have been developed in order to avoid or ameliorate ischemia-reperfusion injury in clinical situations. The application of a sttuter reperfusion after the ischemic event (postconditioning) could alters the hydrodynamics and stimulates endogenous mechanisms that attenuate the reperfusion injury. The present study was designed to evaluate the potential protective effect of postconditioning in a model of ischemia-reperfusion in rats. Methods: Hepatic anterior pedicle of median and left anterolateral segments were exposed and clamped for 1 hour. Two hours later, clamp was released in two different ways: Control Group $(n=7)$ : clamp was release straightforward; Postconditioning Group ( $n=7)$ : clamp was released intermittently. Lipid peroxidation (malondialdehyde) and expression of the glutathione-s-transferase- $\alpha-3$ gene were studied. Results: Lipid peroxidation was significantly decreased in ischemic and non-ischemic liver by postconditioning. GST- $\alpha 3$ gene was overexpressed in postconditioned group, but not significantly. Conclusion: Postconditioning induced hepatoprotection by reducing lipid peroxidation in the ischemic and non-ischemic liver.
\end{abstract}

Key words: Liver. Ischemia. Reperfusion. Lipid Peroxidation. Rats.

\section{RESUMO}

Objetivo: A lesão de isquemia-reperfusão hepática é um fenômeno presente em eventos tais como ressecções hepáticas e transplante de fígado. A restauração do fluxo sangüíneo após a isquemia gera lesões locais e sistêmicas. Várias técnicas foram desenvolvidas com o objetivo de evitar ou diminuir a lesão de isquemia-reperfusão hepática em situações clínicas. A utilização da reperfusão intermitente após o evento isquêmico (pós-condicionamento) pode alterar a hidrodinâmica e estimular mecanismos endógenos que atenuam o dano da reperfusão. O presente estudo foi realizado para avaliar o potencial efeito protetor do pós-condicionamento em um modelo de isquemia-reperfusão em ratos. Métodos: O pedículo dos lobos mediano e ântero-lateral foi isolado e clampeado por 1 hora. Após 2 horas, o pedículo foi liberado de duas maneiras diferentes: Grupo Controle ( $\mathrm{n}=7$ ): clampe liberado de uma só vez; Grupo Pós-condicionamento (n=7): clampe liberado de maneira intermitente. Malondialdeído (MDA) e expressão do gene GST- $\alpha 3$ foram estudadas nos grupos. Resultados: A peroxidação lipídica foi significativamente diminuída no fígado isquêmico e no fígado não isquêmico pelo pós-condicionamento. A expressão do gene GST- $\alpha 3$ aumentou, porém não significativamente, no grupo pós-condicionamento. Conclusão: O pós-condicionamento induziu hepatoproteção pela redução da peroxidação lipídica nos fígados isquêmico e não isquêmico.

Descritores: Fígado. Isquemia. Reperfusão. Peroxidação de Lipídeos. Ratos.

${ }^{1}$ Research performed at Transplantation Division, Laboratory of Medical Investigation \#LIM37, Department of Gastroenterology, Medicine School, University of Sao Paulo (USP), Sao Paulo, Brazil. 


\section{Introduction}

Ischemia-reperfusion injury is a known phenomenon presents in several events like liver resections and transplantation that results in metabolic, structural and functional changes which may lead to cell death ${ }^{1}$.

Several strategies have been described to avoid or ameliorate reperfusion injury in clinical situations. Ischemic preconditioning, intermittent vascular occlusion, anti TNF- $\alpha$ blockers and antioxidants have already been tested in liver reperfusion models ${ }^{2,3}$.

Recently a new strategy, named postconditioning, was described and showed promising results for cardiac reperfusion injury. It consists in application of a gradual, staged or stutter reperfusion after ischemic injury ${ }^{4,5}$.

Only one study in the English literature concerning postconditioning strategy in liver reperfusion injury was published so far. These authors studied the role of mitochondria in cell apoptosis and described a protective effect of ischemic postconditioning, using a gradual reperfusion ${ }^{6}$.

The aim of this study was to evaluate the protective effect of postconditioning using a different strategy, based on stutter reperfusion similar to those successfully used in cardiac postconditioning models.

\section{Methods}

This study was designed in accordance with the Guide for the Care and Use of Laboratory Animals published by the US National Institutes of Health and the Guidelines of Animal Experimentation of the University of São Paulo School of Medicine, Sao Paulo, SP, Brazil, for the care and use of laboratory animals. The experimental protocol was pre-approved by Ethics Commission of the University of Sao Paulo, Brazil.

Fourteen male Wistar rats weighing $250 \pm 5 \mathrm{~g}$ were housed in cages with a controlled 12-h light/dark cycle, receiving water ad libitum. Before the day of experiment the animals fasted overnight but free access to water was allowed. Animals were anestethized with ketamin 5\% (30 mg/kg) and xylazine $2 \%(30 \mathrm{mg} / \mathrm{kg})$ intraperitonially. During the experiment animals were warmed by halogen light $(45 \mathrm{~W}, 127 \mathrm{~V})$ and corporeal temperature was controlled by digital thermometer (YSI Precision 4000A thermometer, USA) and kept around $37^{\circ} \mathrm{C}$. Animals were maintained in spontaneous ventilation with an oxygen-enriched mixture (40\%) during all the procedure.

\section{Experimental design}

Median laparotomy was performed and the pedicle of median and left anterolateral segments was dissected, exposed and clamped with an atraumatic microvascular bulldog clamp (Figure 1).

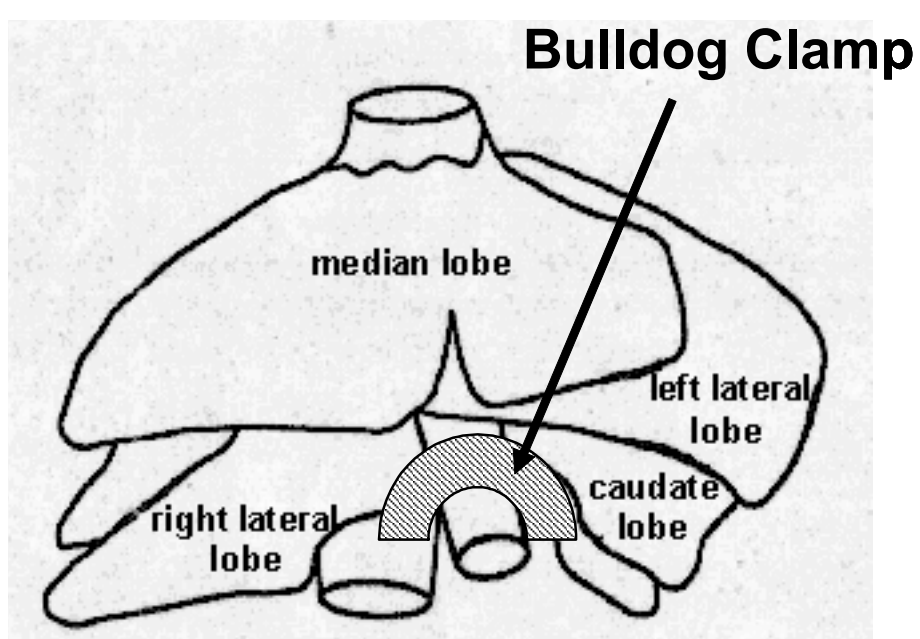

FIGURE 1 - Experimental design of rat ischemic model of partial hepatic ischemia and reperfusion. The pedicle of median and left anterolateral lobes was clamped to promote a devascularization of $75 \%$ of the liver. The blood flow remains stable into the right lateral and caudate lobes

After clamping abdominal wall was closed with ininterrupted 4-0 nylon suture. One hour later, the animals were reoperated and randomly divided in two groups: Control Group (CG): $\mathrm{N}=7$, the clamp was released straightforward; Postconditioning Group (PG): N=7, the clamp was released in a stutter fashion, in 5 periods of 5 seconds of opening, followed of 5 seconds of clamping (Figure 2).
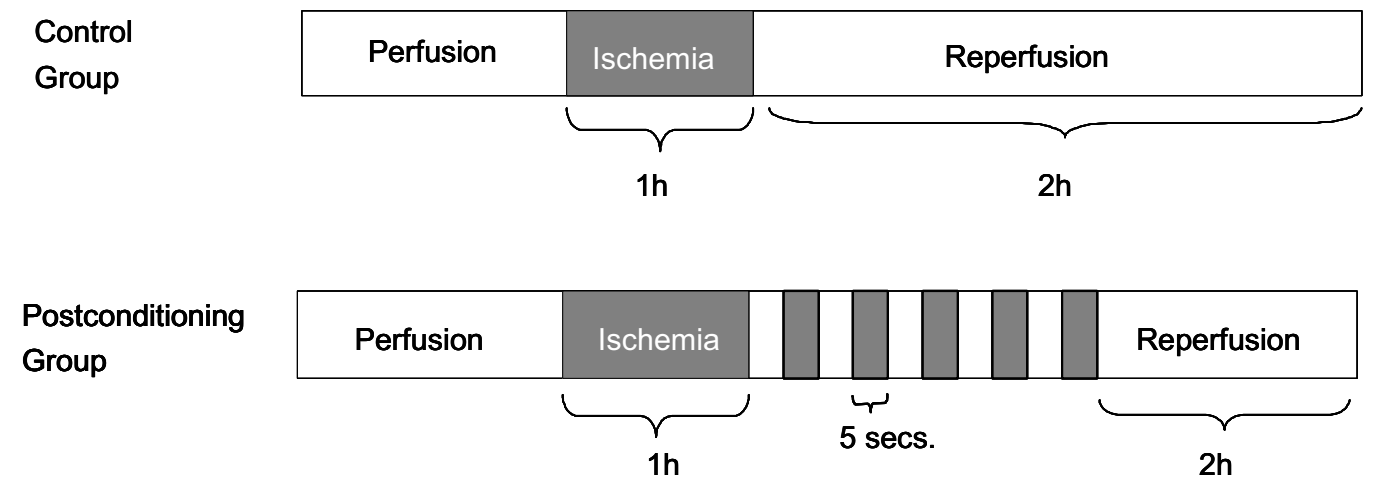

FIGURE 2 - Protocol for postconditioning (intermittent clamping) 
Abdominal wall was closed and animals were observed for two hours (reperfusion period). Animals were then anesthetized and liver was collected for analysis and identified as "ischemic liver" (lobes submitted to ischemia) and "normal liver" (paracaval non-ischemic lobes). Rats were sacrificed by aorta section.

\section{Malondialdehyde analysis}

Malondialdehyde levels in the samples were determined to obtain quantitative estimation of the membrane lipid oxidative damage. Malondialdehyde was assayed in terms of thiobarbituric acid reactive substrats. The thiobarbituric acid method was used to quantify lipid peroxidation in liver, measured as thiobarbituric acid-reactive substances. Liver tissues $(100 \mathrm{mg} / \mathrm{mL})$ were homogeneized in $1.15 \% \mathrm{KCl}$ buffer, and centrifuged at $14,000 \mathrm{~g}$ for $20 \mathrm{~min}$. The supernatant was then stores at $-70^{\circ} \mathrm{C}$. an aliquot of the supernatant was added to a reaction mixture of $1.5 \mathrm{~mL} 0.8 \%$ thiobarbituric acid, $200 \mu \mathrm{L} 8.1 \%$ (v/v) SDS, $1.5 \mathrm{~mL} \mathrm{20 \% (v/v)}$ acetic acid, $\mathrm{pH} 3.5$, and $300 \mu \mathrm{L}$ distilled $\mathrm{H}_{2} \mathrm{O}$, and heated to $90^{\circ} \mathrm{C}$ for $45 \mathrm{~min}$. After cooling to room temperature, the samples were cleared by centrifugation at $10,000 \mathrm{~g}$ for $10 \mathrm{~min}$, and their absorbance was measured at $532 \mathrm{~nm}$ using malondialdehyde bis (dimethyl acetal) as an external standard. The quantity of lipid peroxides is reported in nmol malondialdehyde equivalents/mg protein.

GST- $\alpha 3$ quantitative RT-PCR Analysis: qRT-PCR analysis was performed in the Rotor-Gene RG-3000 (Corbett Research, Sidney, Australia) using SuperScript ${ }^{\mathrm{TM}}$ III Platinum ${ }^{\circledR} \mathrm{SYBR}^{\circledR}$ Green One-Step qRT-PCR kit (Invitrogen, Life Technologies) with $100 \mathrm{ng}$ of total RNA and $0,2 \mu \mathrm{M}$ sense/antisense primer per reaction, according to manufacturer's recommendations. The reaction was carried out under the following cycling conditions: $10 \mathrm{~min}$ at $50^{\circ} \mathrm{C}, 5 \mathrm{~min}$ at $95^{\circ} \mathrm{C}$, followed by 35 cycles of $20 \mathrm{~s}$ at $95^{\circ} \mathrm{C}, 30 \mathrm{~s}$ at $57^{\circ} \mathrm{C}$ and $30 \mathrm{~s}$ at $72^{\circ} \mathrm{C}$. To verify amplification reaction specificity, melting curves were determined using the following parameters: $72{ }^{\circ} \mathrm{C}$ ramping to $99{ }^{\circ} \mathrm{C}$ at $0.2{ }^{\circ} \mathrm{C} / \mathrm{s}$. Primer sets were designed to amplify two separate intron-spanning regions, enabling to assess the possible genomic DNA contamination: GST- $\alpha 3$ sense
5'-GGC GGA TCT GGA TGAAAT AGT TCT-3'; GST- $\alpha 3$ antisense $5^{\prime}$-CAA CGA GAT AAT CTT GTC CAT GGC-3'; $\alpha$-actin sense $5^{\prime}$-TGT CAC CAA CTG GGA CGA TA-3' and $\alpha$-actin antisense 5'-GGG GTG TTG AAG GTC TCA AA-3'. Specificity of product was ensured by melting point analysis and agarose gel electrophoresis to visualize the band for GST- $\alpha 3$ and $\alpha$-actin with the correspondent size; $152 \mathrm{bp}$ and $165 \mathrm{bp}$, respectively. RNA template concentrations (500 ng/ $\mu \mathrm{l}, 100 \mathrm{ng} / \mu \mathrm{l}, 20 \mathrm{ng} / \mu \mathrm{l}, 4 \mathrm{ng} / \mu \mathrm{l}$ and $0.8 \mathrm{ng} / \mu \mathrm{l}$ ) were used to generate a standard curve to evaluate the amplification efficiency of GST- $\alpha 3$ gene in comparison to $\alpha$-actin. RNA content of GST- $\alpha 3$ was determined as the number of transcripts relative to those of $\alpha$-actin and additionally normalized to the mean value of control pancreas and kidney.

Relative quantification was calculated using the mathematical model based on GST- $\alpha 3$ and $\alpha$-actin genes amplification efficiency. All samples were analyzed in duplicate. The results were expressed in arithmetic mean and standard deviation (sd). Collected data were stored in a computer and plot in spread sheets of the Excel program (Microsoft, Seattle, WA, USA).

\section{Statistical analysis}

Comparisons between groups were statistically analyzed using GraphPad Prism 4 software (San Diego, CA, USA). Nonparametric test (Mann-Whitney) was performed since the data distribution was considered as non-Gaussian. Mean values and SEM were displayed in graphics only as additional information. Differences were considered statistically significant when $\mathrm{p}<0.05$.

\section{Results}

The concentration of malondialdehyde was elevated after reperfusion in Control Group (CG) both in ischemic (3.6 \pm 0.53$)$; and non-ischemic $(3.22 \pm 0.52)$ lobes. In the postconditioned group (PG), malondialdehyde was significantly lower in ischemic $(1.56 \pm 0.33)$ and non-ischemic $(0.67 \pm 0.26)$ portions of the liver (Figure 3).
A

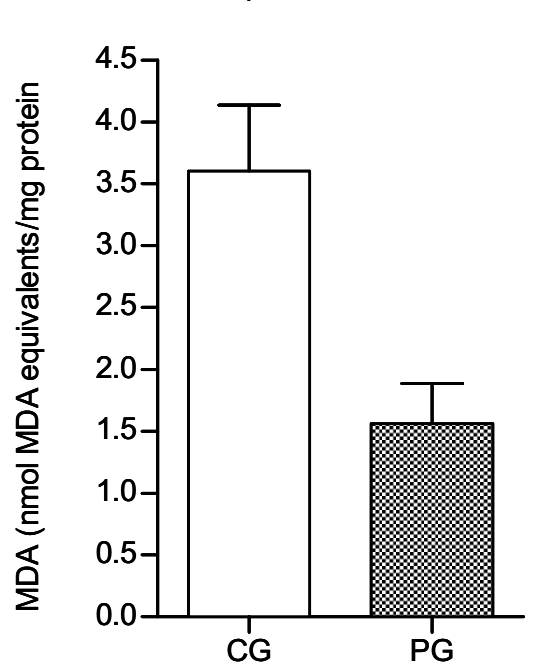

B

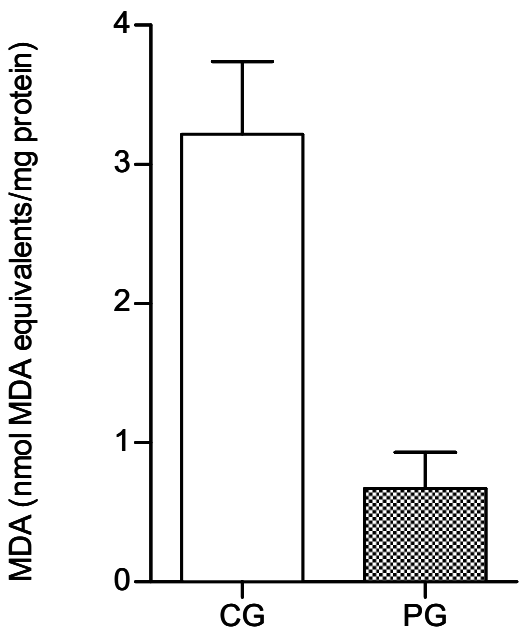

FIGURE 3 - Thiobarbituric acid-reactive substances-malondialdehyde (MDA) equivalents in ischemic (A) and non ischemic liver samples (B) 
Analysis of gene expression of glutathione s-transferase in Control Group (CG) was slightly lower than in the postconditioned group (PG), in ischemic and non-ischemic liver samples, but differences was not significant (Figure 4).

\section{Discussion}

Lipid peroxidation generates a complex variety of products, many of which react with protein and DNA and as a result are toxic and mutagenic ${ }^{7}$. A major target site of lipid peroxidation damage is the cellular membrane because it contains polyunsaturated fatty acids. Toxicity of partially reduced oxygen species arises from the peroxidation of polyunsaturated fatty acid of membrane phospholipids, which may cause membrane disintegration. In liver ischemia-reperfusion injury, this mechanism is exacerbated. The consequent damage to liver cells by reperfusion results in mitochondrial dysfunction and it can also induce microcirculatory disturbances ${ }^{8}$.

Our experiment showed that lipid peroxidation was decreased in the ischemic portion of the liver by postconditioning. This beneficial effect of postconditioning was also identified by Sun et al. ${ }^{6}$. Using a similar model of liver ischemiareperfusion in rats, but with a different protocol of postconditioning, they related that gradual reperfusion minimizes lipid peroxidation and also depress synthesis of free oxygen radicals, preserving mitochondrial ultrastructure and function ${ }^{6}$. Using a rapid stutter reperfusion, we found an important lipid peroxidation reduction in non-ischemic liver that has not been previously described.

In cardiac reperfusion models, postconditioning beneficial effects are related to adenosine. Philipp et al. ${ }^{9}$ described that the protective effect of postconditioning in the rabbit heart is dependent on the occupancy of adenosine receptors ${ }^{9}$ and requires PI3-K and guanylyl cyclase activation ${ }^{10}$. Two reports indicate that endogenous adenosine elicits the infarct-sparing effect of postconditioning by the activation of $\mathrm{A} 2 \mathrm{~B}$ receptor ${ }^{9,11}$. Adenosine is a very important substrate to rebalance the energetic metabolism after reperfusion and it is a potent vasodilator of the microvasculature.

In the liver, we hypothesized that the decrease of lipid peroxidation may also be related to the protective effects of adenosine that remains inside the parenchyma, like in the heart ${ }^{12}$. In our model, we believe that when the clamp is released straightway, reperfusion flow washes out the endogenous protective substances (adenosine amongst them) that have been produced inside the tissue. When a stutter postconditioning is applied, the slow and soft reperfusion flow keeps adenosine and other protective substances inside the liver parenchyma. This also benefits the non-ischemic liver (figure 5).
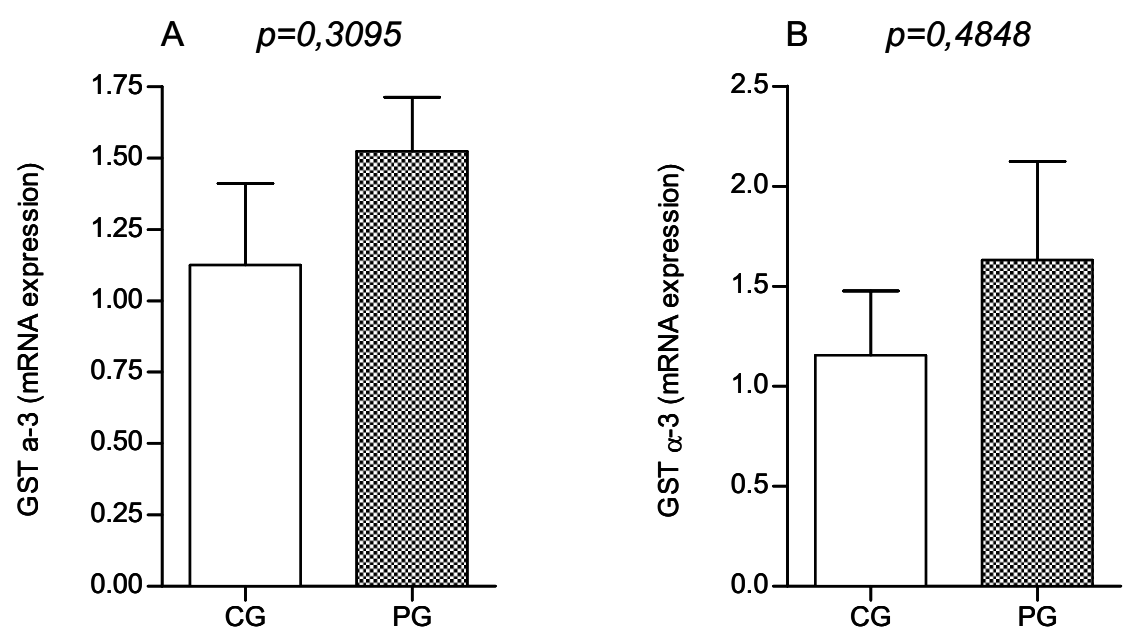

FIGURE 4 - Relative GST $\alpha-3$ mRNA expression levels of in (A) ischemic (CG: 1.12 \pm 0.28 ; PG: $1.52 \pm 0.19)$ and (B) non-ischemic liver (CG: $1.15 \pm 0.32$; PG: $1.63 \pm 0.49$ )

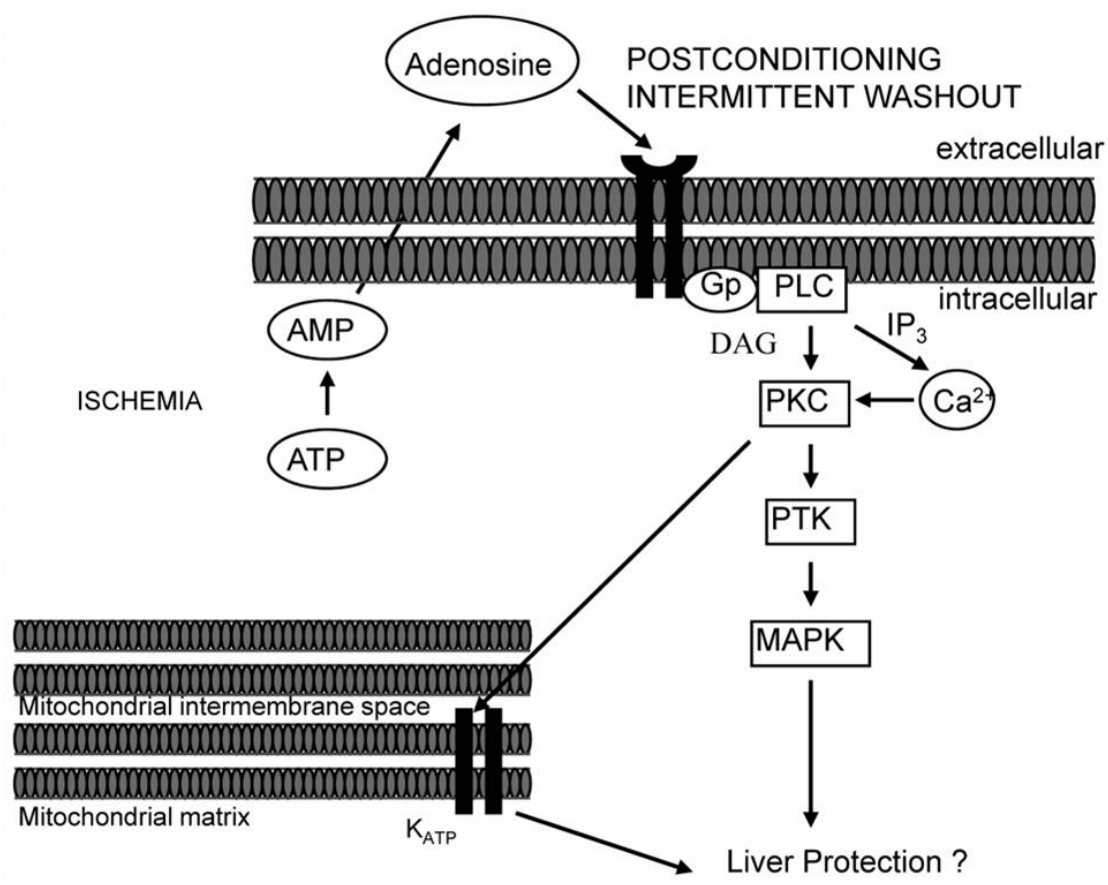

FIGURE 5 - Hypothetical protective mechanism involving adenosine in postconditioning.

The glutathione-s-transferases (GSTs) family comprises cytosolic, mitochondrial and microsomal enzymes involved in the detoxification of endogenous compounds such as peroxidised lipids. They are also important in the metabolism of xenobiotics ${ }^{13}$.

In order to investigate if GST alpha-3 pathway was involved in the protective effect of postconditioning, we performed a real-time RNA analysis. GST- $\alpha 3$ gene was overexpressed in the posconditioned group, both in ischemic and non-ischemic liver. This data, although not significant, reveals a proper tendency.

The application of liver postconditioning strategies in the clinical setting may be useful. In liver transplantation and liver resection, ischemia is very usual and sometimes mandatory. The 
release of vascular clamps after ischemia is normally done straightaway. The intermittent clamp release is a very simple maneuver that may preserve endogenous protective substances inside the liver. Further studies will be addressed in this way.

\section{Conclusion}

Postconditioning induced hepatoprotection by reducing lipid peroxidation in the ischemic and non-ischemic liver in this model of liver ischemia-reperfusion injury in rats.

\section{References}

1. Crisostomo PR, Wairiuko GM, Wang M, Tsai BM, Morrell ED, Meldrum DR. Preconditioning versus postconditioning: mechanisms and therapeutic potentials. J Am Coll Surg. 2006;202:797-812.

2. Minor T, Isselhard W, Yamaguchi T. Involvement of platelet activating factor in microcirculatory disturbances after global hepatic ischemia. J Surg Res. 1995;58:536-40.

3. Glantzounis GK, Salacinski HJ, Yang W, Davidson BR, Seifalian AM. The contemporary role of antioxidant therapy in attenuating liver ischemiareperfusion injury: a review. Liver Transplant. 2005;11:1031-47.

4. Okamoto F, Allen BS, Buckberg GD, Bugyi H, Leaf J. Reperfusion conditions: importance of ensuring gentle versus sudden reperfusion during relief of coronary occlusion. J Thorac Cardiovasc Surg. 1986;92:613-20. 5. Zhao ZQ, Corvera JS, Halkos ME, Kerendi F, Wang NP, Guyton RA, Vinten-Johansen J. Inhibition of myocardial injury by ischemic postconditioning during reperfusion: comparison with ischemic preconditioning. Am J Physiol Heart Circ Physiol. 2003;285: H579-88.

6. Sun K, Liu ZS, Sun Q. Role of mitochondria in cell apoptosis during hepatic ischemia-reperfusion injury and protective effect of ischemic postconditioning. World J Gastroenterol. 2004;10:1934-8.

7. Marnett LJ. Lipid peroxidation-DNA damage by malondialdehyde. Mutat Res. 1999;424:83-95.

8. Giakoustidis D, Papageorgiou G, Iliadis S, Giakoustidis A, Kostopoulou E, Kontos N, Botsoglou E, Tsantilas D, Papanikolaou V, Takoudas D. The protective effect of alpha-tocopherol and $\mathrm{GdCl} 3$ against hepatic ischemia/ reperfusion injury. Surg Today. 2006;36:450-6.

9. Philipp S, Yang XM, Cui L, Davis AM, Downey JM, Cohen MV. Postconditioning protects rabbit hearts through a protein kinase $\mathrm{C}$-adenosine A2b receptor cascade. Cardiovasc Res. 2006;70:308-14.

10. Yang XM, Philipp S, Downey JM, Cohen MV. Postconditioning's protection is not dependent on circulating blood factors or cells but involves adenosine receptors and requires PI3-kinase and guanylyl cyclase activation. Basic Res Cardiol. 2005;100:57-63.

11. Kin H, Zatta AJ, Lofye MT, Amerson BS, Halkos ME, Kerendi F, Zhao ZQ, Guyton RA, Headrick JP, Vinten-Johansen J. Postconditioning reduces infarct size via adenosine receptor activation by endogenous adenosine. Cardiovasc Res. 2005;67:124-33.

12. Ajamieh HH, Candelario-Jalil E, Fernández OS, Gerbes AL. Ischaemic and pharmacological preconditionings protect liver via adenosine and redox status following hepatic ischaemia-reperfusion in rats. Clin Sci. 2008;115(2):69-77.

13. Boyer TD. The glutathione S-transferases: an update. Hepatology. 1989;9:486-96.

Conflict of interest: none Financial source: none

\section{Correspondence:}

Dr. Antonio Roberto Franchi Teixeira

Laboratory of Medical Investigation \#LIM37

School of Medicine, University of Sao Paulo

Av. Dr. Arnaldo, 455/3206

01246-903 Sao Paulo - SP Brazil

Phone: (55 11)3061-8319 / 8558-8426

drrteixeira@uol.com.br

Received: August 27, 2008

Review: October 23, 2008

Accepted: November 25, 2008

\footnotetext{
How to cite this article

Teixeira ARF, Molan NT, Kubrusly MS, Bellodi-Privato M, Coelho AM, Leite KR, Machado MAC, Bacchella T, Machado MCC. Postconditioning ameliorates lipid peroxidation in liver ischemia-reperfusion injury in rats. Acta Cir Bras. [serial on the Internet] 2009 Jan-Feb;24(1). Available from URL: http://www.scielo.br/acb
} 